\title{
William James: \\ On the border between sciences and religion
}

\author{
Mirela Radu', Réka Incze (Kutasi)² \\ ${ }^{1}$ Faculty of Medicine, „Titu Maiorescu University, Bucharest, Romania \\ ${ }^{2}$ Faculty of Medicine, "George Emil Palade“ University of Medicine, Pharmacy, Science and \\ Technology, Tg. Mures, Romania
}

\begin{abstract}
The American physician, William James (1842-1910), a published philosopher and psychologist, will perhaps be forever remembered as the first psychologist in United States. But his influence on universal culture was much deeper. Together with the mathematician and philosopher Charles Sanders Peirce (1839-1914) he laid the foundation for pragmatism. James considers the human mind as a dynamic concept. James also contributed to functional psychology by attempting to define the subconscious in relation to the perception of personal existence. His medical studies led him to perceive psychology as a branch of biology. In the book he published only a year before he passed away, The Meaning of Truth (1909), James postulated radical empiricism. According to the American psychologist, human consciousness is a complex process, not just a data flow, but also the creation of networks and connections between these fragments, and human experience is a cumulative, non-random connection process. Numerous philosophers, sociologists, psychologists, logicians, mathematicians, and even literary writers are indebted to William James for his innovative ideas. The multidisciplinary of this visionary man's theories is unquestionable. He managed to create a system of thinking which blended all the aspects encountered when studying human mind.
\end{abstract}

Keywords: psychology, empiricism, religion, mysticism, medical studies, epistemology

The aim of this article is to show how William James's outstanding personality influenced not only the field of psychology in the U.S.A but also literature and philosophy. Opposing structuralism (theory which decomposes mental processes) by Wilhelm Wundt and Edward Titchener, James forwarded the idea of functionalism which promoted a rational approach. In its turn, this theory proved its influence on occurrence of behaviorism by connecting the apprehension of the newly discovered anatomy of the human mind and its functioning. The influence of his works in psychology and philosophy can traced later on into behaviorism, psychoanalysis, humanism and cognitive psychology. Strongly believing in the possibility of analyzing mind in a correct manner, more analytically, James pointed out towards individual differences, contrasts which make us unique. His theories also had a profound impact on people's education. Stating that we are the product of our mind, that we can change our way of thinking and acting, based on the free will, James brought hope in an emerging society, eager for better education conditions at the turn of last century. By melting together such apparently opposing fields of knowledge (literature, medicine, psychology, philosophy, religion and mystical perspective), James managed to create a unique epistemology on how our mind and reality work, interact and, sometimes, reject each other.

Highly concerned with how our mind works and reacts towards stimuli, in The Varieties of Religious Experience (1902) James makes the difference between existential judgment or proposition and spiritual judgment. Physician by his vocation, James also analysis, from historical point of view, how religion promoted as "geniuses", people who clearly had some sort of emotional disorder: "have often shown symptoms of nervous instability. Even more perhaps than other kinds of genius, religious leaders have been subject to abnormal psychical visitations. Invariably they have been creatures of exalted emotional sensibility. Often, they have led a discordant inner life, and had melancholy during a part of their career. They have known no measure, 
been liable to obsessions and fixed ideas; and frequently they have fallen into trances, heard voices, seen visions, and presented all sorts of peculiarities which are ordinarily classed as pathological" (1).

The author's interest in religious beliefs gave birth to the above-mentioned The Varieties of Religious Experience. A Study in Human Nature. James himself struggled with depression and melancholy. James appeals to reconciliation, to accepting all forms of religion, for the essence of the same is the same: merging with new superior forces, although there are difficulties in explaining mystical or religious experience because there are no notions in philosophy or in science that can provide a radical clarification. James's inclination to supernatural is proven by an episode of his family life. After the death of one of the sons, the fiery philosopher resorted to the services offered by Leonora Piper-a medium. Even though he was not fully aware of his powers of communicating with the spirits, he strongly believed in the telepathic capacities of some people. James was attracted to extreme events of human consciousness. He considered that certain panic states and deep fears can lead the consciousness to a beneficial or pathological development. These devastating events, acting as a catharsis, can change a man and often appeal to "mediums to discover the world beyond our own" (2).

William James's spiritual evolution and profound influence he had in such various fields cannot be fully understood without analyzing his background. James had the chance to be born in a family open to knowledge because his brother Henry James was already devoted to dramaturgy as one of the most prominent figures of American literary realism, and his sister, Alice James, was known to literary circles for her lyrical writings and memoirs, but also for feminist articles. James William had all the strengths to become a complete intellectual. After graduating from Harvard Medical School, his medical involvement was minimal. Although, initially, he had wished to become a physiologist, James summed up the teaching of anatomy and later devoted himself to psychology and philosophy. As part of his epistemological approach, James gets closer to areas of the most diverse and not at all easy: religion, mysticism, metaphysics, psychology. The fragile state of health tended him to reverie that would occupy the central part of his intellectual preoccupations. In 1872 he founded the Metaphysics Club for ten years later his baptism to parapsychology materialized by adhering to the Theosophical Society of Occultism and Kabbalah. Transcendentalism fascinated him.
Thus, he had close contacts with Ralph Waldo Emerson and philosophers (Henri Bergson, Josiah Royce, John Dewey, Macedonio Fernández), physicists (Ernst Mach), sociologists (Walter Lippmann), writers (Horatio Alger, Mark Twain) (G. Stanley Hall, Carl Jung, Sigmund Freud). William James taught psychology, anatomy and philosophy at Harvard, but what really fascinated him and stirred his interest was the study of the human mind. During his stay in Germany, time spent with Hermann Helmholtz, James studied color perception, and in France, with Pierre Janet he came into contact with the way the human mind can dissociate as a result of a traumatic event. The latent question that James attempted to answer throughout his career as a philosopher and psychologist was the elucidation of the way the human mind operates. Being intrigued by the operations of the human brain, James was desperate to find the order behind the way consciousness builds and functions.

James permanently lived on the border between science and religion. He felt attracted equally by both and his inner turmoil gave rise to an innovative way of relating to the extremes of human mind. He regarded the two sides of perceiving the world as being diametrically opposed "The consequence is that the conclusions of the science of religions are as likely to be adverse (...)" (3). The author understands religion as a form of selfishness, a way to survive from spiritual point of view while real evolution from mind point of view is brought about by scientific knowledge "the interest of the individual in his private personal destiny. Religion, in short, is a monumental chapter in the history of human egotism. (...) Science, on the other hand, has ended by utterly repudiating the personal point of view"(3). In The Varieties of Religious Experience James reveals two types of people: once born (people who have an inborn predisposition towards happiness, they are untouched by depression) and twice born people (those of us who believe there is something wrong in our world; they are stigmatized by depression). Twice born people are prone to go through a crisis and are pushed by their will to make sense of existence. Born from a negative state of mind, this positive quest and thus get to a higher plane of life. It is a sort of redemption and salvation comes from inside, a kind of second birth translated by a deeper kind of consciousness. This painful process can be achieved also by religious and mystical experiences. Being happy implies choice, action, active mindset and a misleading of mind by acting "as if". 
A further step is made by James when he connects acquiring knowledge with mystical part within us. The author believes that, by developing a critical mindset we can approach secret worlds within us and above us: "In those more developed minds which alone we are studying, the wrongness takes a moral character, and the salvation takes a mystical tinge" (4). This is the point at which the author relates the inner individual with a common higher conscious. This reality can be achieved only by those spirits who cross the border ordinary reality and step into a form existence simultaneous with the one we live in. James even goes to identifying the way one should take in order to reach the untouchable life: "He becomes conscious that this higher part is conterminous and continuous with a MORE of the same quality, which is operative in the universe outside of him, and which he can keep in working touch with, and in a fashion get on board of and save himself when all his lower being has gone to pieces in the wreck" (5). When one reaches this state of mind, one lives into parallel universes or two dimensions of existence. Religion, as James explains it, is the hope given to mind, is the chance and merely the freedom to choose salvation is the gift given to the human being.

The book that brought him notoriety The Principles of Psychology (1890) was the end of a hard work of twelve years. His moral judgment would influence, say the exegetes, President Jimmy Carter's speech inspired by James, The Moral Equivalent of War, a lecture held in Stanford University in 1906. In this essay, James advocated for a more peaceful world where violence can no longer be a common denominator. Just a few years before the first conflagration began, James had joined a wave of intellectuals who were fighting to stop a possible war. James acknowledges that war has been used throughout the history of humanity as a form of economic cohesion or impulse. But the civilized world no longer needs such mechanisms of social and economic regulation. James states that human beings carry aggression and cruelty in their gene". We inherit the warlike type. (...) Our ancestors have bred pugnacity into our bone and marrow, and thousands of years of peace won't breed it out of us" (6).

James based his reasoning on the fact that, despite the inherited instincts of our ancestors, thinking that characterizes us as finite evaluations would take over the control of some atavistic characteristics. James pleads for a fearsome and rational way of analyzing the facts, for a pacifist attitude, and arbitrarily resolving any potentially dangerous con- flicts for humanity. And these can only be accomplished, according to the author, through education and knowledge, because reason can only be conceived in an orderly manner. Exiting poverty for most of society is, according to the author, the only effective way to get rid of violent primitive instincts and generate empathy. Human altruism can develop in the presence of a minimum of well-being that the members of society can gain. Human latent violence can be redirected towards constructive purposes, concludes the author.

Along with Charles Sanders Peirce (1839-1914), James founded a new philosophical school - pragmatism. This theory postulates that an idea gets meaning if it is sought in its practical effects. Thus, reasoning guides action, and truth can be tested by the practical consequences of belief. Even if, along the $20^{\text {th }}$ century this philosophy waned, as it was supplanted by linguistic philosophy, nowadays it is enjoying a revival, and many contemporary philosophers are returning to James as the inspirer for new theories of perception, meaning, and belief. James has many theories concerning happiness, among them the central idea is that happiness consists in orienting yourself to a higher purpose, even if that purpose cannot prove to exist in rational manner. Those who suffer from a "crisis of meaning" are stronger, endowed with more enthusiasm for life than those who just go through the motions and chose the easy path.

In 1912 Essays in radical empiricism were published. This collection of essays emphasizes the author's concern with the gnoseological conception that considers sensory experience as the sole source of knowledge. Radical empiricism, the theory put forth by James has its foundation in believing that our world is a huge network made up of apparently unconnected things. The smaller structures of our reality, those which can be perceived by sensory perception, create a complex stream of information in which everything is interconnected, and everything has causality. James links the world of perceptions one the one hand with the power of our mind on the other hand. When the two "realities" overlap, we can get the perfect knowledge: "The viscera and cells are only possible percepts following upon that of the outer body. The atoms again, though we may never attain to human means of perceiving them, are still defined perceptually. The mind-stuff itself is conceived as a kind of experience; and it is possible to frame the hypothesis (such hypotheses can be no logic be excluded from philosophy) of two knowers of a piece of mindstuff and the mind-stuff itself becoming 'confluent' 
at the moment at which our imperfect knowing might pass into knowing of a completed type" (7). James considers that the world divides into objective part and the subjective one. He is able to perform the differentiation between the two and this detachment comes from his medical studies: "Sometimes I treat my body as part of the outer nature" (8). The author makes the difference between physical and non-physical existence depending on how narrow or wide the individual chooses to perceive the world. The postulate of radical empiricism is that things are drawn from experience and among them there are connections conjunctive or disjunctive and the directly apprehended universe resides in the relationships among smaller units of reality. Human beings are part of reality but also help building it by the power of their mind "our philosophies swell the current of being, add their character to it" (9). Therefore, reality is a complex construct made up what is already given and to which we add, by our actions, thoughts and perceptions. We are a product and we produce in our turn, in other words.

James deeply studied the power of will and how volitional strength can influence reality. This will can dominate the understanding and the feelings "perception and thinking are only there for behavior's sake" (10). We can build and educate our will by staying committed, focused and alert at all times. The process of building up will starts with the foundation which is purely organic: "Reflex, instinctive, and emotional. movements are all primary performances. The nerve-centers are so organized that certain stimuli pull the trigger of certain explosive parts; and a creature going through one of thesel5 explosions for the first time undergoes an entirely novel experience." This is the first step but the next one is to create concept and even materialize them "when a particular movement, having once occurred in a random, reflex, or involuntary way, has left an image of itself in the memory, then the movement can be desired again, proposed as an end, and deliberately willed" (11). Once the concept is shaped, action is the next phase "the bare idea is sufficient, but sometimes an additional. conscious element, in the shape of a fiat, mandate, or express consent, has to intervene and precede the movement" (12). Build like a pyramid, the reality we live in is first a construct of our mind and then of our actions put in practice. This is the leading idea in all his treatises and essays. Reality is a multi-layered structure which begins in us". Every pulse of feeling which we have is the correlate or some neural activity that is already on its way to instigate a movement. Our sensations and thoughts are but cross sections, as it were, of currents whose essential consequence is motion, and which no sooner run in at one nerve then they run out again at another" (13).

The author's medical studies brought along depression. As his father had had the same mental issues, James strongly believed in inheritance determinism. Upon reading an essay signed by Charles Sanders Peirce, James started strongly believing in our choice "My first act of free will shall be to believe in free will" (14). Later he created a system in which the foundation is made up of reflexes, instincts, and emotions. As soon as we act according to these, the following actions come to strengthen what we achieved in the first phase. Our mind stores this pattern and next time, with each use of that thought, we reinforce it. In other words, we can train our mind what to reason. Free will, as is defined by James, is the information we chose to focus on and by repeating this pattern we create a stream of consciousness and a higher degree of control over our thoughts. Happiness is, according to James, the active role we undergo in life.

In his paper Pragmatism: A New Name for Some Old Ways of Thinking (1907), James presents a further step in self becoming: once you start believing strongly, you can materialize the thought. Depression installs when a person loses the faith in a more profound power in the universe, in a meaning of life. Pessimism feeds depression, anxiety and mental imbalance. Hence, there are two possibilities. Either to consider life as meaningless, point of view adopted by Camus and his existentialism and, on the other hand, the point of view adopted by the representatives of the New Age wave in which science and religion can blend-believing in an order that is beyond our understanding. Nonetheless, James adopts a third way: acting "as if" there is an ultimate meaning of life. By pretending we produce a certainty in our hearts that is denied by the rational mind. That means we trick our rational mind. Once the horizon of one's life points to something beyond it, one is opened to the possibility of achieving very high states of consciousness.

The affinity that the logical thinking has acquired materialized in the attempt to define the truth. James admits that the truth depends on the user of this notion, and the world cannot be the object of a perfectly objective study because any experience brings about change of reality. The American psychologist perceived an interconnection between the tangible world and the human mind. Both cannot only interconnect but also influence 
each other. In his reference work, Principles of Psychology (1890), James advances a new term for his era of "stream of consciousness." By this, James understood that the events to which an individual belongs, his consciousness and his thought make up an indestructible whole which first link and the most important is the inner self of the individual. This perspective would be widely exploited by writers such as James Joyce, Virginia Woolf and Marcel Proust. In the Principles of Psychology, James describes consciousness as a stream of thought, but in his latest A Pluralistic Universe (1909), the author broadens the horizon of understanding from consciousness to being. In this paper he concludes that "mental facts do function both individually and with others at the same time" (15). The hierarchy would be a simple one: consciousness fades in the form of the subconscious and, in its turn the human mind, is part of a wider consciousness. William James, the physicist and philosopher, was contemporary with psychologist Gustav Theodor Fechner (1801-1887) and was aware of his theories in the field of experimental psychology. Just like the German, James comes to the conclusion that there is a universal conscience that includes information of all people. This universal consciousness can be accessed by some of us, as a database. Pluralist pantheism is used by James to pursue the theory of radical empiricism. This common consciousness of humanity is that makes up the good and the Creator. Evil is excluded from this common consciousness.

James applies pragmatism, which he asserted in his career as a philosopher, in identifying the truth. As long as, says the author, a certain idea has proven useful in the reality surrounding us, it acquires the value of truth. And in its turn, reality is made up of states of fact, existing connections between ideas and the totality of the other truths we apply. The utility of truth is the primordial one. If it proves usable and is justifiable, bringing added value, any idea can become truth. Human convictions are a sum of instinct, will, and intellect. The conclusion that emerges from The Will to Believe (1896) is that no one holds the absolute truth. We cannot know whether the choices we make are right or wrong. But whatever path we choose in life, any decision is better than to stand still. From the problem of truth comes another: that of free will. James has formed a two-stage model. The first is the chance (independent of us) and the second is the choice (which belongs to us and is justified by our desires, by character, by our perceptions). Once we make a choice, our brain stores the pattern of making deci- sions and information so that the next decision can be taken. This perspective on the functioning of human reason inspired Henri Poincaré, in his theory of probabilities, as well as the founder of critical rationalism - Karl Popper.

James believed that the mind could be more or less favorable in a certain context. Happiness is, according to James, a construct of our mind. If we take responsibility for our decisions and deeds, giving it a sense of existence, we can achieve happiness. The power of inner decision on the surrounding world seems to be the central theme of his philosophical belief. We are what we decide to be. In modern society, in which science is gaining momentum and religious belief is declining, there is a growing rotten feeling of the lack of finality of existence. If individual is allowed to experience these negative experiences, it only deepens anxiety, fears and, as our times confirm, depression. In an attempt to overcome the deadlock, people can adopt two ways: one directed toward science, denying the existence of the universal Creator, or a religious and mystical one, of accepting an order that goes beyond us. It is the power of the will that opens new horizons. But for the "magic" of optimism to function, it is not enough to believe, we must act as if we were happy. Thus, happiness is a matter of choice, those who manage to achieve this state are the one who decide that lived unhappiness is not an obstacle but an instrument to acquire wisdom.

James's original works gained attention of Carl Jung-the founder of analytic psychology and clearly influenced the field of psychology. Richard Rorty (1931-2007), the American philosopher, places William James in a select lineage at the intersection between neurology, physiology (Pierre Janet) and medicine (Gustav Theodor Fechner and Morton Prince), on the one hand, and the art of writing (Giovanni Papini, HG Wells, George Bernard Shaw). The style of James's writing in his writings is an eclecticism that the author himself lived with. Aware of many foreign languages, contact with European philosophy and culture over the years spent on the old continent, his various readings and even his medical studies left deep traces not only in his personality but also in his expression and experience on the page written "across William's body of writing we see a constant movement back and forth in which the Victorian and the modern, the provincial New Englander and the cosmopolitan transatlanticist, the heroic adventurer and the introspective thinker, all jostle for our attention, sometimes with fine lines or phrases" (16). This cultural diversity that transpires from the lines writ- 
ten by William James is the particularity of his encyclopedic sprite. Three ideas can be found as a common denominator in what William James wrote: pluralism, pragmatism and philosophy of religion. This system of reasoning and reporting oneself to life is one of the most complex one as it mixes personal experiences, medicine, science, religious belief, philosophy and psychology in a unitary scheme that satisfies even the most futilitarian. The main idea is that we can be our own allies or enemies and we can build, in an active way, our own universe.

The freshness of James's perspective in psychology and in medical sciences is that he managed to blend psychology, epistemology and metaphysics into quite a new construct. For James, reality was itself was a mixture of features of the things around us towards which we feel attraction. Although he started his writing career as a psychologist and physician, James often leaves this path and writes as a philosopher. Therefore, he considers science only able to give partial answers. According to his system of perceiving the world, science has only a limited access and should appeal to other branches of human reasoning as well. Thus, science has the role of reminding us the causality relationships it uses in order to make use of this appa-

\section{REFERENCES}

1. James W. The Varieties of Religious Experience. Longmans, Green, And Co.; 1917. p. 10.

2. Ruetenik T. The Demons of William James: Religious Pragmatism Explores Unusual Mental States. Palgrave MacMillan; 2018. p. 12.

3. James W. The Varieties of Religious Experience. Longmans, Green, And Co.; 1917. p. 481.

4. James W. The Varieties of Religious Experience. Longmans, Green, And Co.; 1917. p. 499.

5. James W. The Varieties of Religious Experience. Longmans, Green, And Co.; 1917. p. 499-500.

6. Fischer AM. William James Studies. 1Spring 2018. p. 95.

7. James W. Essays in radical empiricism. New York: Longmans, Green, And Co.; 1912. p. 200.

8. James W. Essays in radical empiricism. New York: Longmans, Green, And Co.; 1912. p. 153.

9. James W. Essays in radical empiricism. New York: Longmans, Green, And Co.; 1912. p. 317 ratus in a more subtle way. Postulating a higher and more complex order of things, science opens the door of knowledge which should be completed with perceptions, concept and will.

James dreams of a new system of thinking which might sum up all human knowledge: "All attempts to explain our phenomenally given thoughts as products of deeper-lying entities (whether the latter be named Soul, Transcendental Ego, Ideas, or Elementary Units of Consciousness) are metaphysical. This book consequently rejects both the associationist and the spiritualist theories; and in this strictly positivistic point of view consists the only feature of it for which I feel tempted to claim originality. Of course, this point of view is anything but ultimate. Men must keep thinking; and the data assumed by psychology, just like those assumed by physics and the other natural sciences, must sometime be overhauled. The effort to overhaul them clearly and thoroughly is metaphysics" (17).

Although a glimpse into the universe that James proposes his readers, the present article makes room for further studying of the complex reality James unveils. The author's theories are nowadays more actual than ever before especially that we realize we are interconnected both physically and in a mental universe.

10. James W. The Will to Believe and Other Essays. London: Longmans, Green, And Co.; 1897. p. 114.

11. James W. Principles of Psychology. II. New York: Longmans, Green, And Co.; 1890. p. 487.

12. James W. Principles of Psychology. II. New York: Longmans, Green, And Co.; 1890. p. 522.

13. James W. Principles of Psychology. II. New York: Longmans, Green, And Co.; 1890. p. 526.

14. Perry RB. The Thought and Character of William James. Vanderbilt University Press; 1996. p. 323.

15. Pawelski JO. Dynamic Individualism of William James. State University of New York Press; 2007. p. 90.

16. Halliwell M, Rasmussen JDS. William James and the Transatlantic Conversation: Pragmatism, Pluralism, and Philosophy of Religion. Oxford University Press; 2014. p. 9.

17. James W. Preface. The principles of psychology. I. New York: New York Henry Holt and Company; 1890. p. VI. 